\title{
Positive degree-day sums in the Alps: a direct link between glacier melt and international climate policy
}

\section{Article}

Cite this article: Braithwaite RJ, Hughes PD (2022). Positive degree-day sums in the Alps: a direct link between glacier melt and international climate policy. Journal of Glaciology 68(271), 901-911. https://doi.org/ 10.1017/jog.2021.140

Received: 24 June 2021

Revised: 20 December 2021

Accepted: 21 December 2021

First published online: 31 January 2022

Keywords:

Climate change; glacier mass balance; glacier meteorology

\section{Author for correspondence:}

Roger J. Braithwaite,

E-mail: r.braithwaite@manchester.ac.uk (c) The Author(s), 2022. Published by Cambridge University Press. This is an Open Access article, distributed under the terms of the Creative Commons Attribution licence (https://creativecommons.org/licenses/by/4.0/), which permits unrestricted re-use, distribution, and reproduction in any medium, provided the original work is properly cited.
Roger J. Braithwaite (1) and Philip D. Hughes

Department of Geography, School of Environment, Education and Development (SEED), University of Manchester, Manchester M13 9PL, UK

\section{Abstract}

Annual balances of eight alpine glaciers were slightly negative for 1961-90 and highly negative for 1991-2018. We explain this by changes in positive degree-day sums and summer temperatures extrapolated to the median altitudes of the glaciers. We test a new way of calculating degreeday sums that performs better than the traditional method which used daily mean temperatures. Annual degree-day sums are highly correlated with May-September temperatures as suggested in 1866 by Karl von Sonklar. We find moderate correlations between annual balances and degreeday sums, and with May-September temperatures. Calculated degree-day factors for the eight glaciers cover the reported range for snow and ice ablation, while the temperature sensitivity of annual balance is from -0.4 to $-1.0 \mathrm{~m}$ w.e. for $\mathrm{a}+1^{\circ} \mathrm{C}$ temperature change. We accurately predict mean balances for 1991-2018 using May-September temperatures in regression models calibrated for 1961-90. May-September temperatures in the Alps have already increased $\sim+3^{\circ} \mathrm{C}$ since 1880 and, if temperatures continue to rise, these glaciers will shrink rapidly. As annual balances are already negative for present-day temperatures, these glaciers will not be 'safe' under the further temperature increase permitted by the Paris Agreement.

\section{Introduction}

From the mid-1980s onwards, glaciologists were increasingly aware of a possible rise in global temperatures with increased glacier melt (Hansen and others, 1981; National Research Council, 1985). This stimulated the development of models that could study increased glacier melting before it happened or, at least, before it was clearly visible.

We can trace this development through papers by Ambach and Kuhn (1985), Oerlemans and Hoogendoorn (1989), Braithwaite and Olesen (1990a), Oerlemans and Fortuin (1992), Oerlemans (1993a, 1993b), Oerlemans and others (1993), Braithwaite and Zhang (1999, 2000) and Kuhn (2000). These experiments suggest an order of magnitude variation in temperature sensitivity of modelled mass balance from $\sim-0.2$ to $-2 \mathrm{~m}$ w.e. $\mathrm{a}^{-1}{ }^{\circ} \mathrm{C}^{-1}$ with smaller sensitivity for dry-continental environments and higher values for wet-maritime environments (Oerlemans and Fortuin, 1992; Braithwaite and others, 2003; de Woul and Hock, 2005; Anderson and others, 2010). Summer-accumulation glaciers should be more sensitive than winter-accumulation glaciers (Sakai and Fujita, 2017) and there should be clear differences in model sensitivity between different regions, and even within regions (Braithwaite and Raper, 2007).

The increased glacier melt envisaged by the National Research Council (1985) is well underway (Zemp and others, 2015, 2019; Marzeion and others, 2018; Thomson and others, 2021), and we can now test model projections from 20-30 years ago with observed data. In the current paper, we study annual balance variations in the Alps and explain them in terms of temperature changes. Figure 1a shows plots of cumulative annual balances and Figure $1 \mathrm{~b}$ shows cumulative temperature deviations for eight glaciers in the Alps with long records up to 2018; see details of the annual balance and climate data later in the paper. It is enough to say here that annual balances in the Alps were rather small (negative or positive) in the 1961-90 reference period and became increasingly negative in the last three decades 1991-2018. The balance changes (Fig. 1a) appear to be associated with increases in summer temperatures since $\sim 1981$ (Fig. 1b). Cumulative balances of these eight glaciers since 1990 are now down to nearly $-60 \mathrm{~m}$ w.e. and these glaciers can probably not survive many more decades in their present form.

We update a degree-day approach in this paper to study annual balance changes of the eight glaciers in the Alps (Fig. 1a), because of its relative economy in terms of input data, its conceptual simplicity, and its connection to the surface energy balance. For example, degree-day factor is the temperature sensitivity of melt, reflecting the temperature sensitivities of the different terms in the energy balance with the largest contributions from sensible heat flux and incoming longwave radiation (Kuhn, 1979; Braithwaite, 1981, 1995; Braithwaite and Olesen, 1990b).

A positive degree-day sum is the sum of air temperatures above the melting point during a period (Cogley and others, 2011), and some past glacier-climate studies assume melt of snow and ice is proportional to this sum (Zingg, 1952; Braithwaite, 1985, 1995, 2011; Hock, 2003; de 


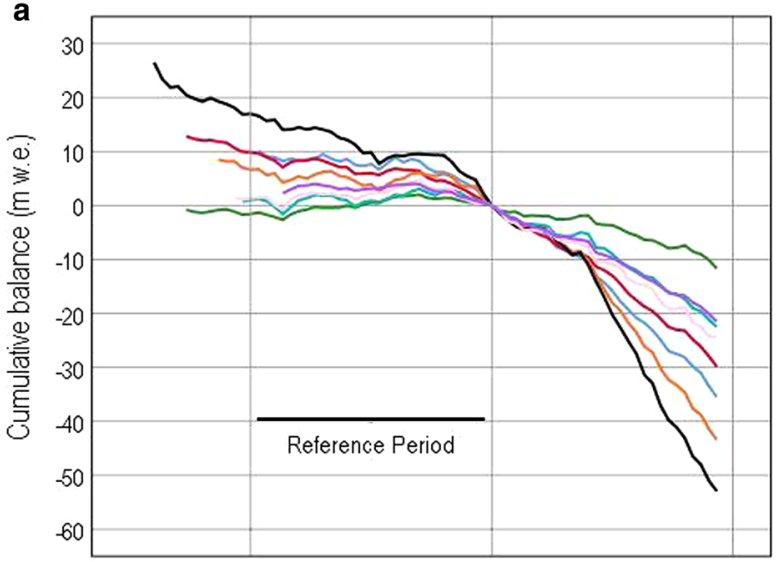

b

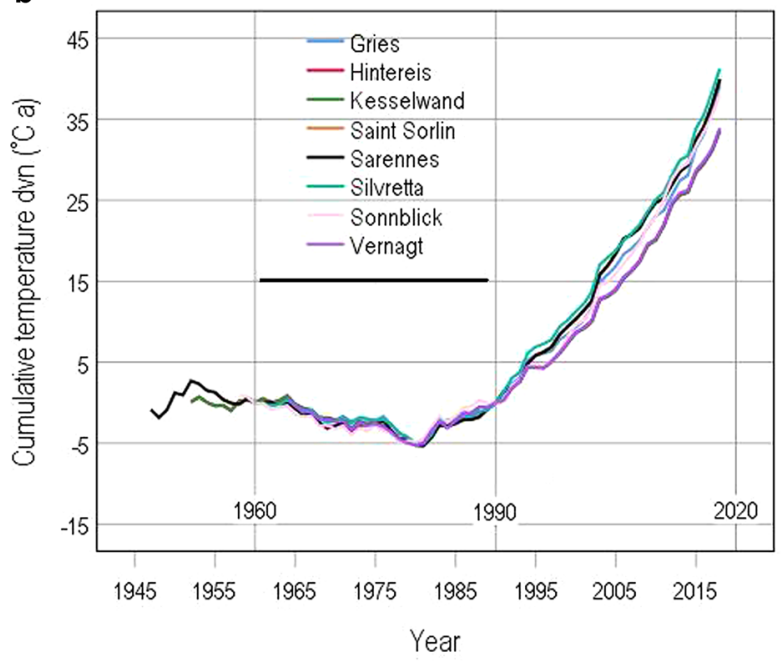

Fig. 1. (a) Cumulative annual balances and (b) cumulative summer temperature deviations for eight glaciers in the Alps. Curves are all zeroed on 1990.

Woul and Hock, 2005). Braithwaite (1985) cited Finsterwalder and Schunk (1887) for the first mention of the degree-day principle in glaciology, but we now find the notion is even older. The Austrian military geographer Karl von Sonklar (18161885) recognised that summer melting (May-September) must balance winter snow accumulation (October-April) at the snowline (von Sonklar, 1858). Von Sonklar (1866, p. 390) suggested calculating snow melt from the positive temperature sum at the snowline, but he noted this is not easily available, and suggested the alternative of using an average summer temperature instead because it is nearly proportional to the positive temperature sum.

Degree-day sums and summer mean temperatures were both widely used as melt indices since mass-balance series became available in the mid-20th century, but few, if any, researchers recognised von Sonklar as the 'godfather' of both approaches. Liestøl (1967) modelled the mass balance of Storbreen, Norway, for 17 years using daily temperature extrapolated from nearby weather stations. Hoinkes and Steinacker (1975) used a similar approach for the mass balance of Hintereisferner, Austria.

Before on-line datasets and spreadsheets were available, extrapolation of daily temperature from a climate station to a glacier seemed cumbersome. Braithwaite (1985) calculated monthly degree-day sums from monthly mean temperatures by assuming a Gaussian distribution for daily mean temperatures within the month. This is efficient as it only needs one temperature (monthly mean) instead of 28-31 daily temperatures. Despite the proliferation of modern databases within the past three decades, historic climate data for monthly mean temperatures are still very much more widely available compared to daily or hourly temperatures.

Reeh (1991) extended the Braithwaite (1985) model by distributing monthly mean temperatures through the year with a sine curve of specified annual range, and mass-balance models of glaciers and the Greenland ice sheet often use this version of the degree-day model. A recent study of French glaciers by Reveillet and others (2017) concludes '... a classical degree-day model is sufficient to simulate the long-term glacier-wide mass balance ....' Within the Greenland community there is continuing interest in improving degree-day models in various ways (Carlov and Greve, 2005; Fausto and others, 2009; van der Broeke and others, 2010; Seguinot, 2013; Rogozhina and Rau, 2014; Jowett and others, 2015; Wake and Marshall, 2015; Tsai and Ruan, 2018).

Many researchers followed Liestøl (1967) in correlating annual balance with summer temperature, and winter or annual precipitation. Braithwaite and Zhang (2000) review such studies, most of which found moderate correlations between annual balance and summer temperature. Glaciers studied in the 20th century were generally close to zero balance without strong areal shrinking or temperature trends during the period of observation. Both conditions are now rare.

Melt, ablation or summer balances are related to degree-day sums according to current usage (Cogley and others, 2011), but we extend the concept to the temperature sensitivity of annual balance. The hypothesis underlying the current paper is:

$$
\Delta B / \Delta T=(\Delta B / \Delta A D D)(\Delta A D D / \Delta T),
$$

where $\triangle B, \triangle A D D$ and $\triangle T$ indicate changes in annual balance $B$ (in $\mathrm{m}$ w.e. $\left.\mathrm{a}^{-1}\right)$, annual degree-day sum $A D D\left({ }^{\circ} \mathrm{C} \mathrm{d} \mathrm{a}{ }^{-1}\right)$ and summer temperature $T\left({ }^{\circ} \mathrm{C}\right)$ between one state and another. According to Eqn (1), the underlying cause of any relation between annual balance and summer temperature is the relation between annual balance and annual degree-day sum $\Delta B / \triangle A D D$, which is like a degree-day factor for annual balance rather than for ablation or melting in the normal definition (Cogley and others, 2011). In the following paper, we derive degree-day sums for each of the glaciers in Figures $1 \mathrm{a}, \mathrm{b}$ and evaluate the three terms in Eqn (1) to account for the increasingly negative annual balances for these glaciers.

Most researchers calculate degree-day sums from observed data by summing the positive values of daily mean temperatures although Arnold and MacKay (1962) pointed out the shortcomings of this. We propose a new approach in Section 3 that addresses their objection.

\section{High-altitude climate stations}

A great achievement of modern climatology is the compilation and publication of data from thousands of weather/climate stations all over world, so the past data are now available for research (Weart, 2008), i.e. accessible to potential users rather than being stored in cellars. The measurement of air temperature, and choice of standard hours for daily mean temperature, was a hot topic during the 19th century (von Hahn, 1903) and different countries used different schemes until recently (Arnold and MacKay, 1962; Linacre and Geerts, 1997). The standard daily report from a climate station to the national data centre (Landsberg, 1958) generally listed daily maximum and minimum temperatures together with mean temperature if calculated on-station.

We identify three high-altitude climate stations in the Alps with century-length daily records in the NOAA dataset (https://www.ncdc.noaa.gov/cdo-web/). These are Säntis, Zugspitze 
Table 1. High-altitude alpine climate stations used in the current study

\begin{tabular}{lcccc}
\hline Station & $\begin{array}{c}\text { Latitude } \\
{ }^{\circ} \mathrm{N}\end{array}$ & $\begin{array}{c}\text { Longitude } \\
{ }^{\circ} \mathrm{E}\end{array}$ & $\begin{array}{c}\text { Elevation } \\
\mathrm{m} \text { a.s.l. }\end{array}$ & Period \\
\hline Vent & 46.5 & 10.8 & 1890 & $1935-2016$ \\
Säntis & 47.3 & 9.3 & 2502 & $1901-2019$ \\
Zugspitze & 47.4 & 11.0 & 2964 & $1901-2019$ \\
Sonnblick & 47.1 & 13.0 & 3106 & $1887-2010$ \\
\hline
\end{tabular}

and Sonnblick (Table 1). The data are 'Daily Summaries' from the Global Historic Climate Network (GHCN) Version 3 (Menne and others, 2012a, 2012b). Daily data for a fourth station (Vent) are available for a shorter period from the PANGAEA database (Institute of Meteorology and Geophysics, 2013; Juen and Kaser, 2016). These latter data are of great interest as this station is located close to three of the glaciers in Figures 1a, b. Hourly observations at these stations are not published, which means we must calculate positive degree-day sums from the daily data. Daily data from the NOAA dataset do not always include daily mean temperature, and we use a method formerly used at simple climate stations (Linacre and Geerts, 1997):

$$
T_{\mathrm{mxmn}}=\left(T_{\max }+T_{\min }\right) / 2
$$

The symbol $T_{\text {mxmn }}$ distinguishes this mean from the conventional mean $T_{\mathrm{mn}}$ that is available for some periods in the NOAA dataset. For 29495 days at Säntis (see below) the mean error between daily data $t_{\mathrm{mxmn}}$ and $t_{\mathrm{mn}}$ is $0.0^{\circ} \mathrm{C}$, with a std dev. of $\pm 0.8^{\circ} \mathrm{C}$, so we deem Eqn (2) to be reasonably reliable.

Monthly mean temperature data to supplement the daily data are also available for Säntis, Zugspitze and Sonnblick from the NASA database (GISTEMP Team, 2020, https://data.giss.nasa. gov/gistemp/). These records are longer than the daily records in the NOAA database and are based on GHCN Version 4. Several other datasets are available but were not suitable for our use, e.g. not completely up to date or not covering the countries of our interest.

We downloaded daily climate data from the NOAA and PANGAEA websites into Excel workbooks, one for each station (available from the authors on request) with one line per day. We discuss the calculation of daily degree-day sums from such observations below. The reader should not conflate this with the calculation of monthly degree-day sums from monthly temperatures by glacier modellers following Braithwaite (1985).

\section{Calculating 'observed' degree-day sums}

Nobody 'observes' degree-day sums directly, and we use the adjective 'observed' to denote degree-day sums derived directly from 'observed' data rather than from models such as by Braithwaite (1985). Calculation is involved in both cases, simple in the first case and more complex in the second case. Glaciologists would like air temperature data to be measured a few times per day, as done by modern automatic weather stations in the last 20-30 years but must work with whatever data are available from historic sources. Braithwaite (1985) tested his method for calculating monthly degree-day sums by comparing them with 'observed' degree-day sums based on daily mean temperatures. Even at the time, Braithwaite (1985) was aware of the objection that air temperature can be above zero for part of the day, even when the daily mean temperature is below zero (Arnold and MacKay, 1962) but there was no obvious alternative in 1985 . We now avoid this problem by defining daily degree-day sums in terms of several temperature observations per day:

$$
p d d_{M}=\frac{1}{M} \sum_{m=1}^{m=M}\left\{\begin{array}{cc}
T_{m}, & T_{m} \geq 0 \\
0, & T_{m}<0
\end{array}\right.
$$

The positive degree-day sum for a day is $p d d_{M}\left({ }^{\circ} \mathrm{C} \mathrm{d}\right)$ and $T_{m}$ is the temperature $\left({ }^{\circ} \mathrm{C}\right)$ measured $M$ times in the day $\left(\mathrm{d}^{-1}\right)$. In a similar way, the fraction of the day with negative temperature is:

$$
n d d_{M}=\frac{1}{M} \sum_{m=1}^{m=M} \begin{cases}1, & T_{m} \geq 0 \\ 0, & T_{m}<0\end{cases}
$$

We have left out indices for days and months to keep notation simple, but we obtain monthly and annual degree-day sums, and annual days with melt, by adding daily values from Eqns (3) and (4).

We assess different methods for calculating daily degree-day sums with a simple simulation experiment. This calculates hourly temperatures from a sine curve for a prescribed daily mean temperature and daily temperature range. We call this method 24 as it uses 24 hourly temperatures. Other methods are: method 1 with $M=1$ and $T_{1}=T_{\text {mean }}$ as used by Braithwaite (1985) and many others; method 2 with $M=2$ and $T_{1}=T_{\max }$ and $T_{2}=$ $T_{\text {min }}$; and method 4 with $M=4$ and $T=T_{\max }, T_{3}=T_{\text {mean }}$ and $T_{4}=T_{\min }$. Equation (2) is the inspiration for methods 2 and 4. Method 24 is 'best', as it corresponds to the true daily mean according to Conrad and Pollack (1962), and our purpose here is to see which of the other methods comes close to method 24 if we are unable to use it.

Figure 2 shows simulated daily degree-day sum for the different methods with daily temperature range $10^{\circ} \mathrm{C}$. Three zones are visible: (1) zero degree-day sum for daily mean temperatures below $-5^{\circ} \mathrm{C}$ for all methods; (2) non-linear increases of degreeday sum for daily temperature between -5 and $+5^{\circ} \mathrm{C}$ and (3) linear increase of degree-day sum for temperature above $+5^{\circ} \mathrm{C}$ for all methods. In zone 1, all hourly temperatures are below zero and in zone 3 , all hourly temperatures are above zero. The daily temperature range determines the width of the intermediate zone 2 .

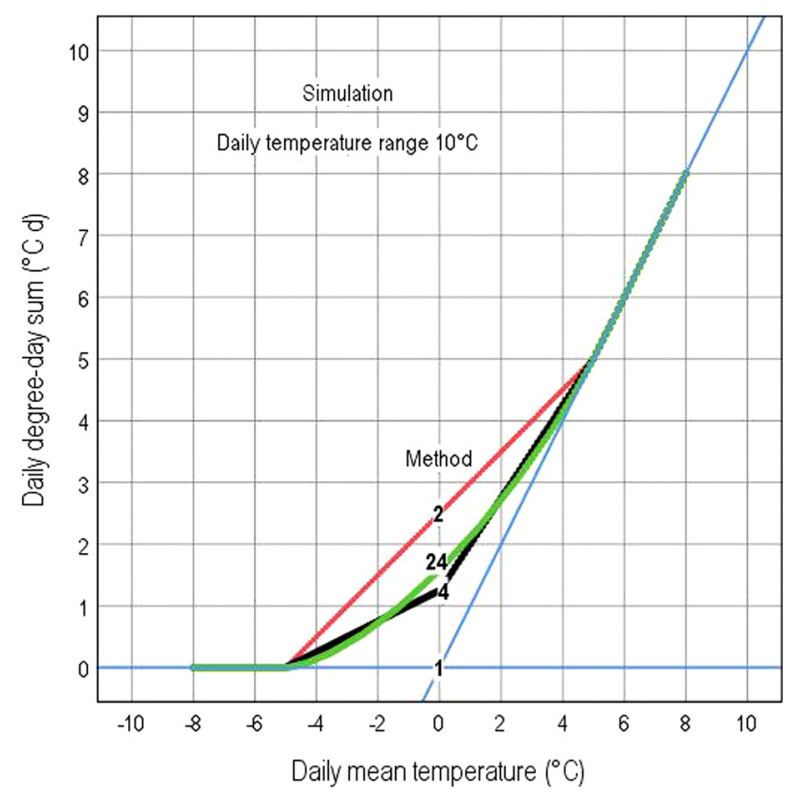

Fig. 2. Simulation of daily degree-day sums for four different methods: (1) from daily mean; (2) from daily maximum and minimum; (3) from daily mean, maximum and minimum and (4) from 24 hourly observations. 
Compared with method 24 in Figure 2, method 1 seriously underestimates and method 2 seriously overestimates degree-day sum at $0^{\circ} \mathrm{C}$. Method 4 gives two straight lines in the intermediate zone 2 rather than a curve like method 24 but otherwise closely agrees with it. The assumed sinusoidal temperature variation for calculating method 24 cannot be exactly true (Conrad and Pollack, 1962; Linacre and Geerts, 1997) but it is reasonable to use method 4 if hourly temperatures are not available for method 24 . The underestimation by method 1 is noteworthy as it confirms Arnold and MacKay (1962).

\section{Degree-day sums at climate stations}

We calculate monthly degree-day sums by adding up daily degreeday sums at all stations (using method 4 , see above) for all months with at least 25 days of data, and re-scale the degree-day sums for months with up to 6 days of missing data to the full length of the month, i.e. $28,29,30$ or 31 days, if need be.

Figure 3 shows 'observed' monthly mean degree-day sums for all four climate stations, i.e. monthly totals of degree-days divided by the length of month to avoid the small inhomogeneity of plotting data with different lengths of month. As first found by Braithwaite (1985), there is a clear non-linear relation between monthly mean degree-day sums and monthly mean temperatures, similar to the simulation in Figure 2 except that the transition zone 2 is wider in Figure 3. Presumably, this reflects some daily temperature ranges $>10^{\circ} \mathrm{C}$. The plotted curve in Figure 3 is based on a modification of the Braithwaite (1985) model whereby the monthly std dev. is given by a linear function of monthly mean temperature as suggested by Wake and Marshall (2015) rather than a constant as assumed by Braithwaite (1985). The model curve follows the scatter of points quite well but may underrepresent cases where high degree-day totals occur within months with low monthly mean temperatures, e.g. in Föhn-type weather conditions.

We calculate annual degree-day sums from monthly sums if data are available for all 12 months (or available for at least 25 days in each month), otherwise we leave a gap in the record. Von Sonklar (1866) suggested that degree-day sums are proportional to summer mean temperatures which he assumed to be

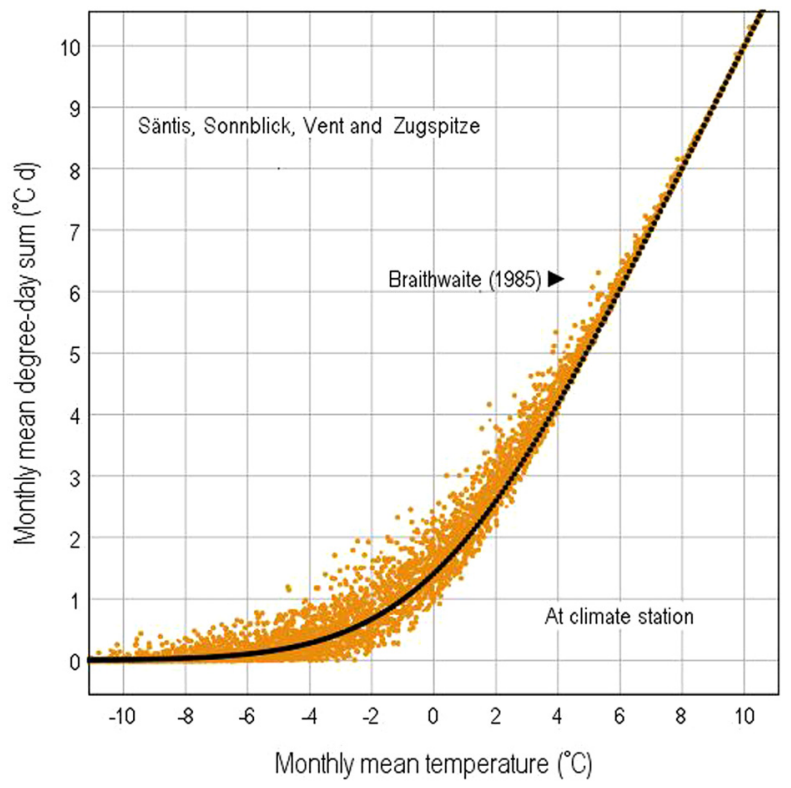

Fig. 3. Monthly degree-day sums (method 4) at four high-altitude climate stations in the Alps compared with monthly mean temperatures. The smooth curve is from the Braithwaite (1985) model. for May-September. Climatologists have long defined 'summer' as from June to August (von Hahn, 1903) but we calculate several different averages of summer temperature: $T_{6-8}$ for June-August; $T_{6-9}$ for June-September; $T_{5-9}$ for May-September; $T_{5-10}$ for May-October. There are generally high correlations between annual degree-day sum and the different estimates of summer temperature as suggested by von Sonklar. However, the usual choice of summer temperature $\left(T_{6-8}\right)$ gives slightly lower correlation coefficients with annual degree-day sums $(r=0.80-0.91)$ than Von Sonklar's favoured $T_{5-9}(r=0.91-0.93)$. For the two 'warmest' stations, Säntis and Vent, May-October temperatures give the highest correlations with annual degree-day sum ( $r=0.96$ in both cases) while $T_{6-9}$ gives the highest correlations $(r=0.93$ and 0.94$)$ for the two 'coldest' stations, Sonnblick and Zugspitze. A rigorous analysis of these statistics would involve careful significance testing but, for this paper, we use von Sonklar's choice of $T_{5-9}$ as a pragmatic choice for summer temperature. We hope to re-consider this issue in a future paper when we have degree-day sums from widely different regions.

Figure 4 shows the relation between annual degree-day sums and May-September temperatures for all four climate stations. The multiple correlation coefficient for the curve $(r=0.99)$ indicates a very high level of 'explanation' of degree-day sums by summer temperatures. The relation is non-linear, although it might appear linear for the restricted range of temperatures at a single station, e.g. the linear sensitivity of annual degree-day sum to temperature change varies from 81 to $178 \mathrm{~d} \mathrm{a}^{-1}$ for the four stations as given in Figure 4.

Reeh (1991) shows a more general relation between (modelled) annual degree-day sums and summer temperatures, whereby there are separate curves for different annual temperature ranges (also see Hughes and Braithwaite, 2008; Hughes, 2009a). The four stations in Figure 4 have very similar temperature ranges, i.e. averages of $17-19^{\circ} \mathrm{C}$, so it is reasonable to plot a common curve through the point scatter, but researchers should only use this curve for glaciers in the Alps or in similar environments.

\section{Degree-day sums at glaciers}

Table 2 shows locations and periods of record for the eight glaciers shown in Figs 1a, b. To keep tables to a manageable

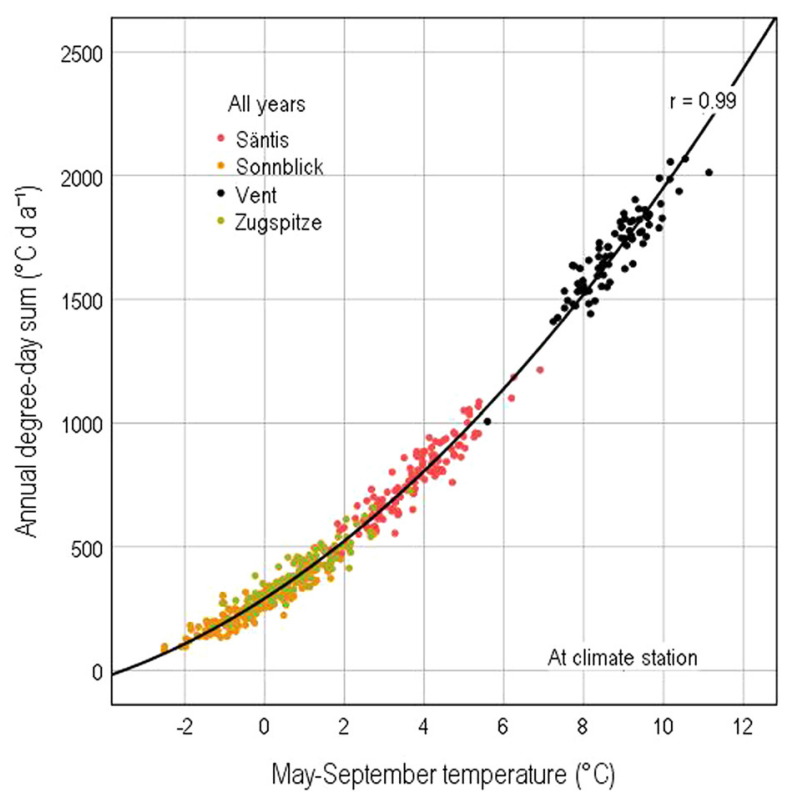

Fig. 4. Annual degree-day sums versus May-September temperatures at four highaltitude climate stations in the Alps. 
Table 2. Eight reference glaciers in the Alps. Data from WGMS (2020).

\begin{tabular}{lcccc}
\hline Glacier & $\begin{array}{c}\text { Latitude } \\
{ }^{\circ} \mathrm{N}\end{array}$ & $\begin{array}{c}\text { Longitude } \\
{ }^{\circ} \mathrm{E}\end{array}$ & $\begin{array}{c}\text { Altitude } \\
\mathrm{m} \text { a.s.l. }\end{array}$ & Period \\
\hline Hintereis & 46.8 & 10.8 & 3070 & $1953-2018$ \\
Kesselwand & 46.8 & 10.8 & 3190 & $1953-2018$ \\
Sonnblick & 47.1 & 12.6 & 2780 & $1959-2017$ \\
Vernagt & 46.9 & 10.8 & 3150 & $1965-2018$ \\
Gries & 46.4 & 8.3 & 2940 & $1962-2018$ \\
Silvretta & 46.9 & 10.1 & 2780 & $1960-2018$ \\
St Sorlin & 45.2 & 6.2 & 2900 & $1957-2018$ \\
Sarennes & 45.1 & 6.1 & 2905 & $1949-2018$ \\
\hline
\end{tabular}

width, we have shortened glacier names by omitting words and syllables meaning 'glacier' in German or French.

The climate station Vent is close to three of the eight glaciers (Hintereis, Kesselwand and Vernagt) and Sonnblick station is close to Sonnblick Glacier. We extrapolate daily mean, maximum and minimum temperature readings from the stations to the median altitudes of the nearby glaciers using a vertical lapse rate of $-0.006^{\circ} \mathrm{C} \mathrm{m}^{-1}$. This lapse rate fits well with the altitude distribution of 30 year monthly mean temperatures in Switzerland (Begert and others, 2003). We choose the median altitude for the extrapolation because the annual balance at this altitude should be roughly equal to the annual balance for the whole glacier (Xie and others, 1996; Braithwaite, 2015), and because this altitude is available for more than $10^{5}$ glaciers in the Randolph Glacier Inventory (Pfeffer and others, 2014). We calculate daily and annual degree-day sums from the extrapolated daily data for the four glaciers in the same way as we did for the four climate stations.

The four western glaciers in Table 2 (Gries, Silvretta, Saint Sorlin and Sarennes) are not located near high-altitude climate stations with long records. We estimate annual degree-day sums at these glaciers in several steps: (1) we extrapolate temperatures from a gridded climatology to the median altitudes of the four glaciers; (2) we use a modification of the Braithwaite (1985) model, see Figure 3, to calculate monthly degree-day sums from monthly temperatures and (3) we add monthly degree-day sums to give annual degree-day sums. For the temperature extrapolation in (1) we use monthly mean temperatures at the nearest $0.5^{\circ}$ latitude/longitude grid square in the high-resolution gridded climatology from the Climatic Research Unit (CRU) at the University of East Anglia (UEA) (Harris and others, 2020). The centres of the chosen grid squares are at distance of $13-22 \mathrm{~km}$ from the glaciers in question. We tested (2) and (3) in the above procedure by calculating annual degree-day sums at the four climate stations where we already have annual degree-day sums from observations. Figure 5 illustrates this.

The modelled values agree very well with observations near the origin but underestimate higher degree-day sums by $\sim 5 \%$. This may be due to the non-zero degree-day sums at very low temperatures as already noted in Figure 3. We 'correct' the annual degreeday sums using the regression line in Figure 5. RMSE associated with the regression line in Figure 5 is $\pm 25^{\circ} \mathrm{C} \mathrm{d} \mathrm{a}^{-1}$ for the four climate stations, and we assume that corrected annual degree-day sums at Gries, Silvretta, Saint Sorlin and Sarennes have similar RMSEs. We could have used the non-linear regression in Figure 4 to calculate degree-day sums at these glaciers, but the RMSE is larger, i.e. $\pm 53^{\circ} \mathrm{C} \mathrm{d} \mathrm{a}{ }^{-1}$.

The annual degree-day sums at the different glaciers are strongly correlated with May-September temperatures (Fig. 6). Although the slopes of the linear regression lines are different for different glaciers, they closely cluster around a mean slope $108 \mathrm{~d} \mathrm{a}^{-1}$. A comparison of Figures 4 and 6 shows that the straight lines in Figure 6 are approximations to the more non-linear

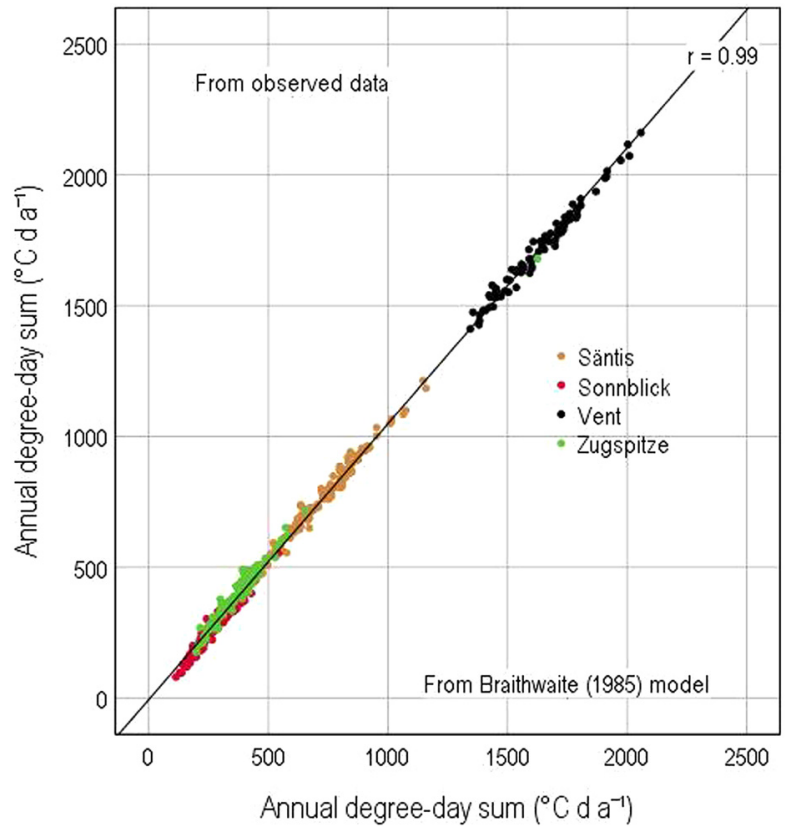

Fig. 5. Annual degree-day sums at four high-altitude stations in the Alps versus annual degree-day sums calculated by the Braithwaite (1985) model.

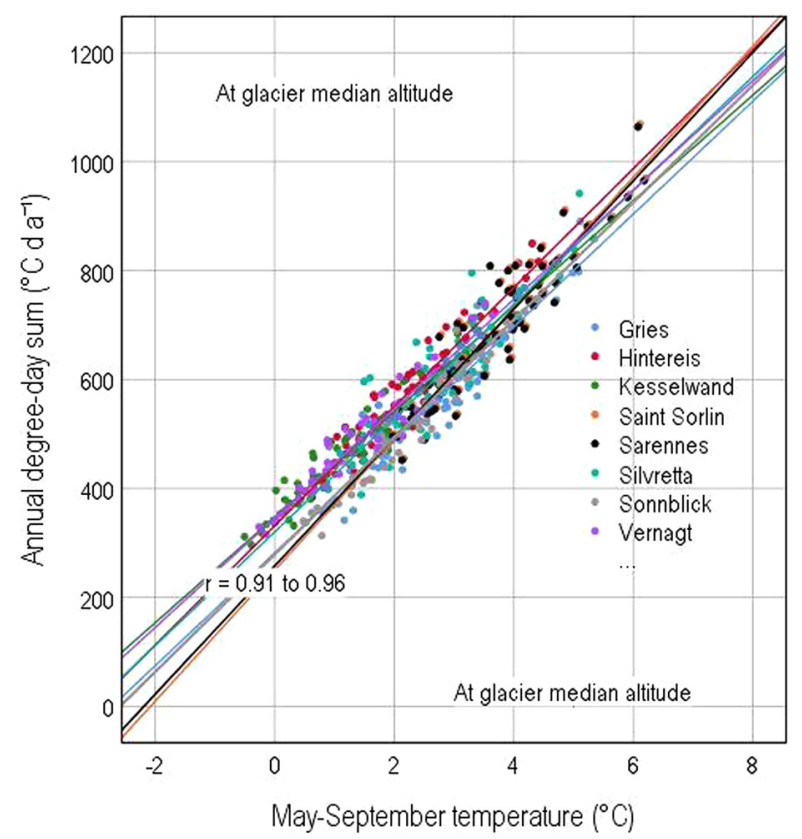

Fig. 6. Annual degree-day sums versus May-September temperatures extrapolated to median altitudes of eight glaciers in the Alps.

relation in Figure 4. We treat the different slopes of the regression lines in Figure 6 as estimates of $\triangle A D D / \Delta T$ in Eqn (1) and we discuss them in the following section.

\section{Glacier balances and degree-day sums}

The annual balance data from the eight glaciers given in Table 2 are whole-glacier averages of balances measured in a network of stakes and snow pits, i.e. what we used to call 'mean specific balance' (Anonymous, 1969; Cogley and others, 2011). The everlengthening series from these glaciers are listed in successive WGMS publications over the last few decades and belong to the WGMS set of reference glaciers (WGMS, 2020). There are some 
other long mass-balance series from Switzerland (Huss and others, 2015) in the most recent WGMS database, but we prefer not to use them for the current study. This is not because there is anything wrong with such series per se but because they are based on re-analysis of long archived field data by various methods, including temperature-index melt modelling, and we want to be sure that any balance-temperature relations we find are not artefacts added to the data.

The glaciers in Table 2 are not 'representative' of glaciers in the Alps: they are simply eight glaciers selected for measurement many decades ago by various researchers and now selected by us for study because of their long records.

Records for the eight glaciers in Table 1 started in different years. Annual balance series measured over many decades are unlikely to be perfectly homogeneous in a statistical sense. Aside from changes in personnel and procedures over the decades of measurement, the sampling space for averaging data from stakes and snow pits changes as the area and altitude distribution of the glaciers change over the decades. Any statistics calculated from such long mass-balance series will therefore reflect average geometry for the period of record for the glacier in question. Vincent and others $(2017,2021)$ suggest that point measurements of mass balance may better represent the effect of climate on glaciers, but we do not think that we should yet discard the rich treasure of many decades of whole-glacier averages.

Several researchers, e.g. Zemp and others (2015), show cumulative curves of annual balance similar to those in Figure 1a but, as an innovation, we adjust the cumulative plots to a common zero for 1990 to allowing easier comparison between curves. We choose 1990 as the zero-point because it is the end of the 1961-90 reference period used for the CRU/UEA gridded climatology (New and others, 1999) that we find useful for glacier-climate research. To our knowledge nobody has plotted cumulative curves of temperature deviations as we do in Figure $1 \mathrm{~b}$, but it shows temperature variations over time more clearly than a simple plot of temperatures versus time. Comparing Figures 1a, b gives the strong impression that rising summer temperatures (Fig. 1b), starting in 1981, may be forcing increasingly negative balances (Fig. 1a). The forcing is rather similar for the different glaciers while responses are rather different. We explore this in more detail in the following section.

Annual balances for the eight glaciers depend on annual degree-day sums (Fig. 7a) and summer temperatures (Fig. 7b). The plots look very similar to each other aside from the units on the $x$-axes because the high correlations between degree-day sums and temperatures (Fig. 6) means that Figure $7 \mathrm{~b}$ is close to a linear transform of Figure 7a. Correlations for annual balance are not especially large for some of the glaciers, but degree-day sums 'explain' at least $50 \%$ of the variance of annual balances for each glacier. Presumably, snow accumulation accounts for part of the unexplained $50 \%$ of variance. We could have followed Hoinkes and Steinacker (1975) who modified their degree-day sums to take account of winter and summer snowfalls, and thus increased their correlations. However, in the current paper, we concentrate on relations between annual balances and temperature variables.

Plots of annual balances calculated by the regression lines in Figures $7 \mathrm{a}$, b show remarkable agreement for each glacier, indicating that annual degree-day sums and May-September temperatures are equivalent in 'explaining' the same balance variations over the years.

The intercepts in the regression equations in Figures $7 \mathrm{a}, \mathrm{b}$ have no obvious meaning as they seem too large to be estimates of annual accumulation, i.e. values of annual balance when melting is zero. Ignoring the negative signs and differences in units, the slopes of the regression lines in Figure $7 \mathrm{a}$ are like degree-day factors for ice or snow melting (Zingg, 1952; Braithwaite, 1985, 1995, 2011; Hock, 2003; de Woul and Hock, 2005). We treat the regression coefficients in Figure $7 \mathrm{a}$ as estimates of $\Delta B$ / $\triangle A D D$, as defined by Eqn (1), and the regression coefficients in Figure $7 \mathrm{~b}$ as estimates of $\Delta B / \Delta T$ the temperature sensitivity of annual balance.

Table 3 shows estimates of the three sensitivity parameters in Eqn (1) based on the regression coefficients in Figures 6, 7a, b, i.e. using all available data for each glacier. Values in column 5 are the products of columns 3 and 4 . According to the simple theory in Eqn (1), values in columns 2 and 5 should be the same but nobody can expect perfect agreement due to the various errors in each parameter. Columns 2 and 5 agree in giving Kesselwand the a

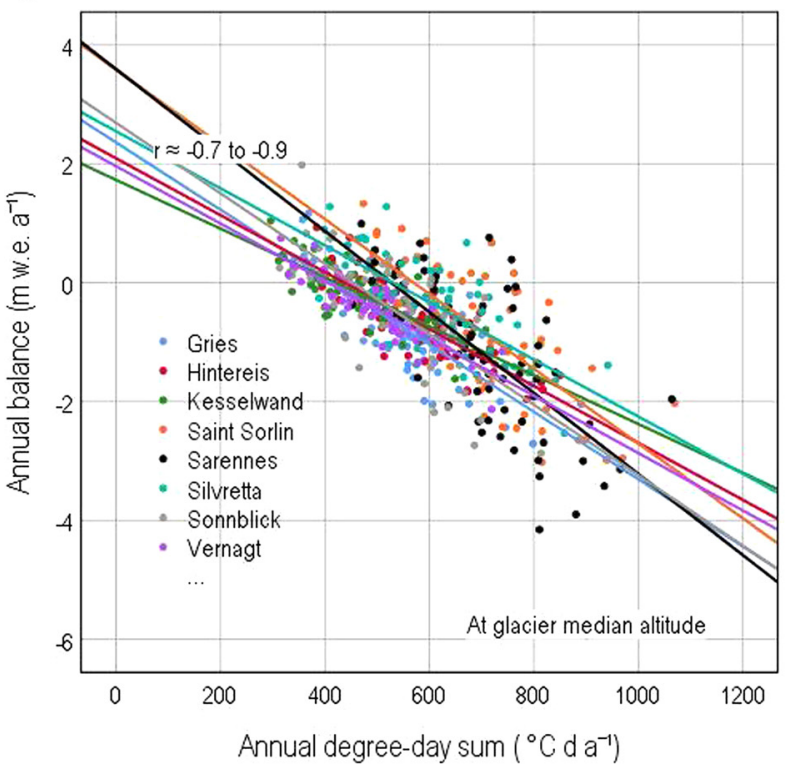

b

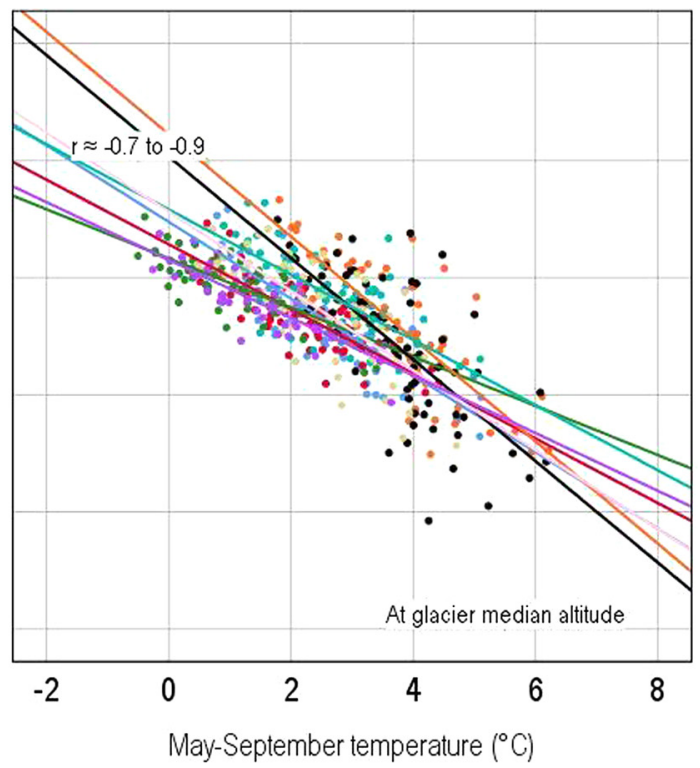

Fig. 7. Annual balances for eight glaciers in the Alps versus (a) annual degree-day sums and (b) May-September temperatures extrapolated to the median altitudes of the glaciers. 
Table 3. Changes of annual balance $B$ (m w.e. $\left.\mathrm{a}^{-1}\right)$, annual degree-day sum $A D D$ $\left({ }^{\circ} \mathrm{C} \mathrm{d} \mathrm{a}{ }^{-1}\right)$ and summer temperature $T\left({ }^{\circ} \mathrm{C}\right)$ for eight glaciers in the Alps. Column 5 is the product of columns 3 and 4 . Analysis uses all available data for each glacier.

\begin{tabular}{lcccc}
\hline $\begin{array}{l}\text { Glacier } \\
(1)\end{array}$ & $\frac{\Delta B}{\Delta T}$ & $\frac{\Delta B}{\Delta A D D}$ & $\frac{\Delta A D D}{\Delta T}$ & \\
\hline Hintereis & $(2)$ & $(3)$ & $(4)$ & $(5)$ \\
Kesselwand & -0.55 & -0.0048 & 109 & -0.52 \\
Sonnblick & -0.42 & -0.0041 & 97 & -0.40 \\
Vernagt & -0.68 & -0.0059 & 108 & -0.64 \\
Gries & -0.49 & -0.0048 & 100 & -0.48 \\
Silvretta & -0.66 & -0.0057 & 104 & -0.59 \\
Saint Sorlin & -0.56 & -0.0048 & 104 & -0.58 \\
Sarennes & -0.87 & -0.0063 & 120 & -0.76 \\
Mean & -0.87 & -0.0068 & 118 & -0.80 \\
\hline
\end{tabular}

lowest temperature sensitivity for annual balance, i.e. lower than for its close neighbour Hintereis, while Saint Sorlin and Sarennes have the highest temperature sensitivities. The low values of degree-day factor in column 3 and temperature sensitivity of degree-day sum in column 4 for Kesselwand, and the high values for Saint Sorlin and Sarennes explain this pattern.

The temperature sensitivity of degree-day sums should be easy to estimate for any glacier with temperatures extrapolated to the glacier. In contrast, it is difficult to know the appropriate degreeday factor before studying the relation between annual balance and annual degree-day sums. Modellers such as Braithwaite and others (2003) and Braithwaite and Raper (2007) assume that increased melting at the glacier median altitude occurs with a prescribed degree-day factor appropriate for ice melt, i.e. $\sim 6-8 \mathrm{~mm}$ $\mathrm{d}^{-1}{ }^{\circ} \mathrm{C}^{-1}$ by assumption. By contrast, the degree-day factors in column 3 cover a range of values, suggesting that year-to-year variations in annual balance involve different proportions of ice and snow melt. We return to this point in discussion of Table 4.

\section{Glacier balances for 1961-2018}

When the first author worked on statistics for mass-balance data (Braithwaite, 1977), colleagues said regression equations might explain variations for a certain period but did not necessarily predict variations outside that period. We test this in a simple way in the present section by splitting the dataset into two roughly equal samples: sample 1 for 1961-90 when changes in mean annual balances and summer temperatures were relatively small according to Figures 1a, b, and sample 2 for 1981-2018 when changes were larger.

We assume that annual balance is related to temperature by the regression Eqn (5) where $T_{5-9}^{*}$ is the May-September

Table 4. Regression equations for annual balance $\left(m\right.$ w.e. $\left.a^{-1}\right)$ versus summer temperature deviation $\left({ }^{\circ} \mathrm{C}\right)$ for eight glaciers in the Alps. The intercept (column 2 ) is $\alpha\left(\mathrm{m}\right.$ w.e. $\left.\mathrm{a}^{-1}\right)$, the regression coefficient (column 3$)$ is $\beta\left(\mathrm{m}\right.$ w.e. $\mathrm{a}^{-1}{ }^{\circ} \mathrm{C}^{-1}$ ) and the correlation coefficient (column 4) is $\gamma$ (dimensionless). Length of series is from 26 to 30 years.

\begin{tabular}{lccc}
\hline $\begin{array}{l}\text { Glacier } \\
(1)\end{array}$ & $\alpha$ & $\beta$ & $\gamma$ \\
Hintereis & $(2)$ & $(3)$ & $(4)$ \\
Kesselwand & -0.32 & -0.62 & -0.77 \\
Sonnblick & +0.05 & -0.41 & -0.71 \\
Vernagt & -0.04 & -0.65 & -0.66 \\
Gries & -0.10 & -0.47 & -0.83 \\
Silvretta & -0.34 & -0.84 & -0.81 \\
Saint Sorlin & -0.03 & -0.66 & -0.66 \\
Sarennes & -0.22 & -0.97 & -0.81 \\
Mean & -0.57 & -0.93 & -0.76 \\
\hline
\end{tabular}

temperature expressed as a deviation from the 1961-90 mean:

$$
B_{a}=\alpha+\beta T_{5-9}^{*}
$$

The $\alpha$ and $\beta$ parameters in Eqn (5) are the intercept and slope of the equation and we evaluate them by regression analysis of data for the period 1961-90 at each glacier.

As the mean of $T_{5-9}^{*}$ must be zero for 1961-1990, the intercept $\alpha$ is equal to the mean balance for 1961-90 at each glacier. Table 4 lists values of $\alpha$ and $\beta$ together with correlation coefficients. The average of the intercepts $\alpha$ in column 2 is small and negative, indicating that mean balances were close to zero in 1961-90 for most of the glaciers. The values of $\beta$ in column 3 of Table 4 are close to those in columns 2 and 5 of Table 3, and differences probably reflect differences of sampling. The most noteworthy difference is for Gries.

The parameters $\alpha$ and $\beta$ are inversely related. Four glaciers in Table 4 (Kesselwand, Sonnblick, Vernagt and Silvretta) have 1961-90 balances $\alpha$ close to zero and lower values of $\beta$, i.e. -0.4 to $-0.7 \mathrm{~m}$ w.e. $\mathrm{a}^{-1} \mathrm{C}^{-1}$, while four other glaciers (Hintereis, Gries, Saint Sorlin and Sarennes) have strongly negative balances for 1961-90 and higher values of $\beta$, i.e. -0.6 to $-1.0 \mathrm{~m}$ w.e. $\mathrm{a}^{-1} \mathrm{C}^{-1}$. In the first group, variations in annual balance mainly reflect variations in melting snow (with lower degree-day factor) while balance variations in the second group mainly reflect variations in melting ice (with higher degree-day factor). Increased accumulation of dust on retreating glaciers may decrease albedo, and increase degreeday factors, in a positive feedback loop (Oerlemans and others, 2009) while accumulation of a thicker debris-layer will decrease degree-day factors (Juen and others, 2014; Winter-Billington and others, 2020).

Figure 8 shows the observed and predicted balances for 19912018 for the eight glaciers. The observed balances are from Figure 1a while the predicted balances use the regression parameters in Table 4 with temperature deviations for each glacier and each year in the period 1991-2018. In other words, we use a model calibrated with 1961-90 data to predict 1991-2018 balance.

Except for Gries, as already noted, agreement between the predicted and observed values of balance is good (Fig. 8). This confirms increasing summer temperatures as the cause of increasingly

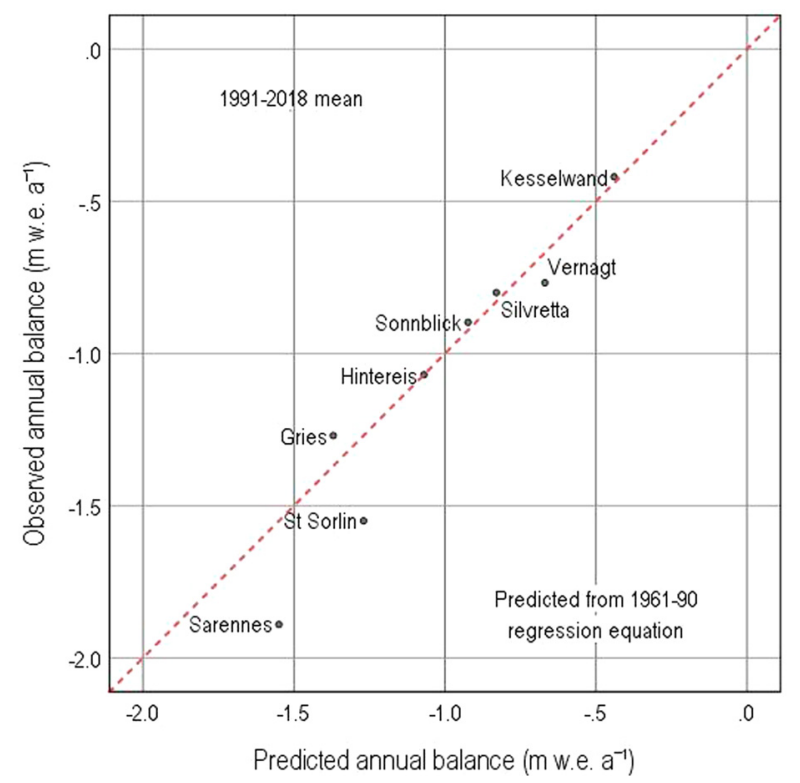

Fig. 8. Observed balances for 1991-2018 at eight glaciers in the Alps versus balances predicted from balance-temperature regression equations for 1961-90. 
negative balances in the period 1991-2018. Differences in the $\alpha$ and $\beta$ parameters explain differences between individual glaciers. For example, Kesselwand has a much lower balance than its close neighbour Hintereis because it has a small positive mean balance for 1961-1990 combined with a low temperature sensitivity in Table 4. Sarennes and Saint Sorlin both have large balances because they already had substantially negative mean balances for 1961-1990 combined with high temperature sensitivities in Table 4.

Variations in both $\alpha$ and $\beta$ parameters in Table 4 contribute roughly equally to the variations in the predicted balances in Figure 8. We can speculate about the effect of future temperature changes on these glaciers. For example, what happens if we could somehow 'restore' summer temperatures to the 1961-1990 average? The glaciers Kesselwand, Sonnblick, Vernagt and Silvretta are close to balance $\left(+0.05\right.$ to $-0.10 \mathrm{~m}$ w.e. $\left.\mathrm{a}^{-1}\right)$ for $1961-1990$ and their increasingly negative balances for 1991-2018 are mainly due to temperature rise. For the other four glaciers, the negative balances for $1961-90\left(-0.22\right.$ to $-0.57 \mathrm{~m}$ w.e. $\left.\mathrm{a}^{-1}\right)$ are strong contributors to their 1991-2018 balances, and future summer temperatures would need lowering below the 1961-1990 average to restore zero balance. For example, the mean balance of the eight glaciers is $+0.01 \pm 0.22 \mathrm{~m}$ w.e. $\mathrm{a}^{-1}$ for $1961-1980$ with a mean temperature deviation $-0.25 \pm 0.05^{\circ} \mathrm{C}$ relative to the 1961-1990 mean.

The reader should avoid the temptation of quoting any figures here as averages for all glaciers in the Alps. The closest to an estimate of mean annual balance for the Alps is the value $-0.87 \pm$ $0.07 \mathrm{~m}$ w.e. $\mathrm{a}^{-1}$ for 2006-2016 given in Table 1 of Zemp and others (2019) for Central Europe (mainly comprising the Alps). The equivalent value for our eight glaciers is $-1.3 \pm 0.6 \mathrm{~m}$ w.e. $\mathrm{a}^{-1}$. If we suppose that Saint Sorlin and Sarennes are local 'anomalies', the mean balance for the remaining six glaciers is $-1.0 \pm$ $0.3 \mathrm{~m}$ w.e. $\mathrm{a}^{-1}$, which is still more negative than the average quoted by Zemp and others (2019).

The increasingly negative balances in Figure 1a suggest these glaciers will shrink rapidly in the coming decades with continued temperature rise, but we are reluctant to say they will 'disappear'. This is because very small glaciers have different mass-balance regimes compared with larger cirque and valley glaciers (Kuhn, 1995) and may become decoupled from regional climate and its changes. Local topographic and climatic controls such as avalanching and windblown snow, debris cover and strong shading influence the mass balances of very small glaciers (Hughes, 2008, 2009b; Hughes and others, 2020). In Albania, Hughes (2009b, p. 458) notes that 'local topoclimatic factors may render these glaciers insensitive to regional climatic changes'. Huss and Fischer $(2016$, p. 1) note that ' $52 \%$ of all very small glaciers in Switzerland will completely disappear within the next 25 years. However, a few avalanche-fed glaciers at low elevation might be able to survive even substantial atmospheric warming'. Thus, the findings of our paper are more relevant for larger valley and cirque glaciers, and the fate of very small glaciers requires further study.

\section{Century-scale temperature variations in the Alps}

From the foregoing, we see that summer temperatures have a strong control on variations in glacier mass balances in the Alps. We want to use climate data from several countries in and around the Alps to investigate variations in summer temperatures over the 20th and early 21 st centuries and use monthly data from the NASA website (https://data.giss.nasa.gov/gistemp/). It is disturbing that some climate stations started operating in 1880 (or even earlier) but stopped in the early 21st century and are therefore not available for future monitoring. We identify eight low-altitude stations (Basel,
Hohenpeissenburg, Innsbruck, Klagenfurt, Lugano, Salzburg, Sion 2 and Zürich) with complete monthly temperature records for 1880-2020. There are also monthly data from Col St Bernard (altitude $2472 \mathrm{~m}$ a.s.l.) to supplement the three high-altitude stations in Table 1 with century-long records.

The 12 stations are a little biased to the northeast of the eight glaciers, but we can use data from a further three stations (Geneve, Lyon and Torino) southwest from our glaciers by combining data from closely neighbouring stations. This uses the method of differences and works well when one station has a record back to 1880 , a nearby station has a record up to 2020 , and both stations have complete records for 1961-90. We need data up to September 2020 to calculate May-September temperatures for all years, and these were already available from the NASA website by mid-October 2020 when we looked for them.

Figure 9 shows year-to-year variations of May-September temperatures for the 15 stations (in light brown) as deviations from their respective 1961-90 means. We calculate separate averages for the 11 low- and the four high-altitude stations in each year and smooth both with 5 year running means (with triangular weights) plotted as black or red traces in Figure 9. The two traces are remarkably similar while Ohmura (2012) found larger deviations at higher altitude.

There are substantial year-to-year variations throughout the record in Figure 9, including 'spikes' of high temperature in $1911\left(+1.1^{\circ} \mathrm{C}\right.$ above $1961-90$ mean $), 1917\left(+1.2^{\circ} \mathrm{C}\right), 1947\left(+2.4^{\circ}\right.$ C) and $2003\left(+3.3^{\circ} \mathrm{C}\right)$, as well as some multi-year excursions. There is a slight trend of rising temperatures from 1880 to $\sim 1930$ (with a significant cold excursion on the way), followed by roughly constant temperatures until the early 1980s (with a significant warm excursion in the 1940s). The present trend of rising temperatures up to 2020 appears to have started in 1981 (Fig. 1b), immediately after a cold excursion in the late 1970s. For the period 1991-2018, summer temperature has a trend of $+0.044^{\circ} \mathrm{Ca}^{-1}$ (with a correlation coefficient of 0.46 ). As the 20th-century temperature record in and around the Alps involved several large $\left( \pm 1^{\circ} \mathrm{C}\right)$ 'excursions' in running averages of temperature, the present trend of rising temperatures would not have been clearly apparent much sooner than the early 2000s, when

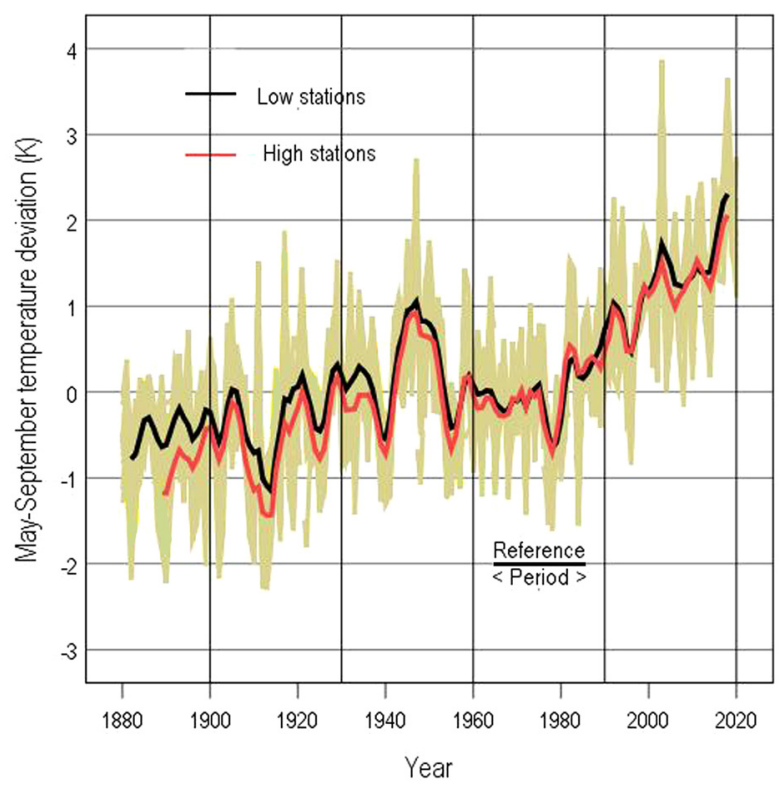

Fig. 9. May-September temperature deviations from 1880 to 2020. Deviations are from the 1961-90 reference period at 15 stations in and around the Alps. The black and red curves show 5 year running averages for 11 low- and four high-altitude stations. 
smoothed temperature deviations first exceeded the 1947 temperature spike.

Figure 9 suggests an overall May-September temperature change of $\sim 3^{\circ} \mathrm{C}$ in and around the Alps from the late-19th to early-21st centuries. This century-scale increase of temperature is larger than the global average increase of temperature, e.g. see Figure 4 in Riseby and others (2018), and may seem larger than $1.28 \pm 0.34^{\circ} \mathrm{C}$ reported by Begert and Frei (2018) for homogenised June-August data for Switzerland. However, the latter comes from a regression line of temperature versus year, and the smoothed plots of temperature versus year in Figure 2 of Begert and Frei (2018) do not seriously falsify the temperature change we quote above.

Climatic changes in a region like the Alps must be complex (Brönnimann, 2015; Kuhn and Olefs, 2020) but we think the recent temperature trend in the Alps may be a regionally enhanced response to global warming (Hansen and Sato, 2016; Hansen and others, 2016). If the Alps are really warming faster than the global average, this would explain why glaciers in Central Europe (mainly comprising the Alps) have the fourth most negative mean balance for 2006-16 of all the 19 glacier regions in Table 1 in Zemp and others (2019).

\section{Implications for climate policy}

Hansen and others (1981) and the National Research Council (1985) alerted an earlier generation of glaciologists to possible increased glacier melting and sea-level rise as a result of what we now call 'global warming'. From the late 1980s, the Intergovernmental Panel on Climate Change (IPCC) has compiled information on climate change and provided periodic assessments to policymakers (Houghton, 2009). The latest summary for policymakers of the Sixth Assessment Report is IPCC (2021). The current international climate accord on climate change is the Paris Agreement (https://unfccc.int/process-andmeetings/the-paris-agreement/the-paris-agreement) agreed in 2015 , whereby the parties agree to reduce greenhouse gas emissions to limit future global temperatures rises to +1.5 to $+2^{\circ} \mathrm{C}$ above pre-industrial levels.

Although global temperatures have not yet exceeded the limit allowed by the Paris Agreement glaciers all over the world show greatly increased mass loss under the climate of the early 21 st century (Zemp and others, 2015, 2019; Marzeion and others, 2018, Thomson and others, 2021). For the glaciers of the Alps, the regional temperature rise is greater than the global temperature rise, leading to very negative balances. Glaciers are therefore not 'safe' even under current global climate let alone that permitted by the Paris Agreement. Aside from their known importance for water resources, global sea level and the environment, 'Glaciers have a particular place in the human imagination, and a particular status as symbols or icons in fiction, poetry, music, painting and other representations' according to Knight (2019). It would be a great pity if glaciers were no longer part of the landscape.

\section{Summary and conclusions}

Annual balances of eight alpine glaciers (Hintereis, Kesselwand, Sonnblick, Vernagt, Gries, Silvretta, St Sorlin and Sarennes) were close to balance for 1961-90 and increasingly negative for 19912018. We explain this in terms of changes in positive degree-day sums and summer temperatures in and around the Alps:

- We test a new way to calculate positive degree-day sums from observed temperatures, which accounts for diurnal temperature variations and performs better than the traditional method using daily mean temperatures.
- Annual degree-day sums at high-altitude climate stations are highly correlated with summer temperature as first suggested in 1866 by von Sonklar.

- We estimate annual degree-day sums and summer temperatures at the median altitudes of the eight glaciers. Annual balances for all glaciers are moderately correlated with degree-day sums and with May-September temperatures.

- We accurately predict increasingly negative mean balances for 1991-2018 using May-September temperatures for 1991-2018 together with a regression model calibrated with 1961-90 balance data.

- The temperature sensitivity of annual balance changes are from -0.4 to $-1.0 \mathrm{~m}$ w.e. $\mathrm{a}^{-1}{ }^{\circ} \mathrm{C}^{-1}$ for the eight glaciers. We explain this sensitivity by variations in degree-day factors from -0.004 to $-0.007 \mathrm{~m} \mathrm{~d}^{-1}{ }^{\circ} \mathrm{C}^{-1}$. This covers the range of degreeday factors reported in the literature for both ice and snow melt.

- May-September temperatures at 15 climate stations in and around the Alps increased $2^{\circ} \mathrm{C}$ from 1961 to 2018 , and by $\sim 3^{\circ} \mathrm{C}$ from 1880 . These temperature increases are greater than global temperature rises and may explain highly negative balances in the Alps compared with other glacial regions.

Acknowledgements. The University of Manchester has supported RJB with an Honorary Senior Research Fellowship since 2010. The editor and two anonymous referees made constructive comments on the first draft of this paper. We use archived climatological data from NOAA (https://www.ncdc. noaa.gov/cdo-web/), PANGAEA (https://doi.org/10.1594/PANGAEA876595), NASA (https://data.giss.nasa.gov/gistemp/) and UEA (https://crudata.uea.ac. $\mathrm{uk} / \mathrm{cru} / \mathrm{data} / \mathrm{hrg} /$ ), and glacier mass-balance data from WGMS (http://dx.doi. org/10.5904/wgms-fog-2020-08). We are deeply grateful to all those who fund, compile, validate and maintain such databases for use by the wider community. Such data monitoring is very important now as we watch glaciers shrink before our eyes.

\section{References}

Ambach W and Kuhn M (1985) Accumulation gradients in Greenland and mass balance response to climatic changes. Zeitschrift für Gletscherkunde und Glazialgeologie 21(1), 311-317.

Anderson, BA and 6 others (2010) Climate sensitivity of a high-precipitation glacier in New Zealand. Journal of Glaciology 56(195), 114-128.

Anonymous (1969) Mass-balance terms. Journal of Glaciology 52(8), 3-7.

Arnold KC and MacKay DK (1962) Different methods of calculating mean daily temperatures and their effects on degree-day totals in the high Arctic and their significance to glaciology. Geographical Bulletin 21, 123-129.

Begert $\mathbf{M}$ and 5 others (2003) Homogenisierung von Klimamessreihen der Schweiz und Bestimmung der Normwerte 1961-1990. Veröffentlichungen MeteoSchweiz Nr. 67.

Begert M and Frei C (2018) Long-term area-mean temperature series for Switzerland: combining homogenized station data and high-resolution grid data. International Journal of Climatology 38(6), 2792-2807.

Braithwaite RJ (1977) Air temperature and glacier ablation - a parametric approach (PhD thesis). McGill University, Montreal, Canada.

Braithwaite RJ (1981) On glacier energy balance, ablation, and air temperature. Journal of Glaciology 27(97), 381-391.

Braithwaite RJ (1985) Calculation of degree-days for glacier-climate research. Zeitschrift für Gletscherkunde und Glazialgeologie 20, 1-8.

Braithwaite RJ (1995) Positive degree-day factors for ablation on the Greenland ice sheet studied by energy-balance modelling. Journal Glaciology 41(137), 153-160.

Braithwaite RJ (2011) Degree-Days. In Singh VP, Singh P and Haritashya UK (eds.) Encyclopedia of Snow, Ice and Glaciers. Encyclopedia of Earth Sciences Series. Dordrecht: Springer, pp. 196-199. doi: 10.1007/978-90481-2642-2_104.

Braithwaite RJ (2015) From Doktor Kurowski's Schneegrenze to our modern glacier equilibrium line altitude (ELA). The Cryosphere 9, 2135-2148. 
Braithwaite RJ and Olesen OB (1990a) Increased ablation at the margin of the Greenland ice sheet under a greenhouse-effect climate. Annals of Glaciology 14, 20-22.

Braithwaite RJ and Olesen OB (1990b) Response of the energy balance on the margin of the Greenland ice sheet to temperature changes. Journal of Glaciology 36(123), 217-221.

Braithwaite RJ and Raper SCB (2007) Glaciological conditions in seven contrasting regions estimated with the degree-day model. Annals of Glaciology 46, 297-302.

Braithwaite RJ and Zhang Y (1999) Modelling changes in glacier mass balance that might occur as a result of climate changes. Geografiska Annaler 81A(4), 489-496.

Braithwaite RJ and Zhang Y (2000) Sensitivity of mass balance of five Swiss glaciers to temperature changes assessed by tuning a degree-day model. Journal of Glaciology 46(152), 7, 14.

Braithwaite RJ, Zhang Y and Raper SCB (2003) Temperature sensitivity of the mass balance of mountain glaciers and ice caps as a climatological characteristic. Zeitschrift für Gletscherkunde und Glazialgeologie 38(1), 35-61.

Brönnimann S (2015) Climatic changes since 1700. Advances in Global Change Research 55. Heidelberg: Springer.

Carlov R and Greve R (2005) A semi-analytical solution or the positive degree-day model with stochastic temperature variations. Journal of Glaciology 51(172), 173-175.

Cogley JG and 10 others (2011) Glossary of glacier mass balance terms and related terms (IHP-VII Technical Documents in Hydrology No. 86, IACS Contribution No. 2) UNESCO-International Hydrological Programme, Paris.

Conrad V and Pollack LW (1962) Methods in Climatology, 2nd Edn. Cambridge, Massachusetts: Harvard University Press.

de Woul M and Hock R (2005) Static mass-balance sensitivity of Arctic glaciers and ice caps using a degree-day approach. Annals of Glaciology 42(1), 217-224.

Fausto RS, Ahlstrøm AP, van As D, Bøggild CE and Johnsen SJ (2009) A new present-day temperature parameterization for Greenland. Journal of Glaciology 55(189), 95-105.

Finsterwalder S and Schunk H (1887) Der suldenferner. Zeitschrift des Deutschen and Österreichischen Alpenvereins 18, 72-89.

GISTEMP Team (2020) GISS Surface Temperature Analysis (GISTEMP), version 4. NASA Goddard Institute for Space Studies (Dataset accessed 2020-10-15. Available at https://datagiss.nasagov/gistemp/).

Hansen J and 6 others (1981) Climatic impact of increasing atmospheric carbon dioxide. Science 213, 957-966.

Hansen J and 18 others (2016) Ice melt, sea level rise and superstorms: evidence from paleoclimate data, climate modeling, and modern observations that $2^{\circ} \mathrm{C}$ global warming could be dangerous. Atmospheric Chemistry and Physics 16, 3761-3812. doi: 10.5194/acp-16-3761-2016

Hansen J and Sato M (2016) Regional climate change and national responsibilities. Environmental Research Letters 11, 034009. doi: 10.1088/1748-9362/ $11 / 03009$

Harris I, Osborn TJ and Jones P (2020) Version 4 of the CRU TS monthly high-resolution gridded multivariate climate dataset. Science Data 7, 109. doi: 10.1038/s41597-020-0453-3.

Hock R (2003) Temperature index melt modelling in mountain areas. Journal of Hydrology 282, 104-115.

Hoinkes H and Steinacker R (1975) Zur Parametrisierung der Beziehung Klima-Gletscher. Verhandlungen der Dreizahnten Internationalen Tagung für Alpen Meteorologie. Rivista Italiana di Geofisica e Dinamica Quaternaria 1, 97-104.

Houghton J (2009) Global Warming: The Complete Briefing, 4th Edn. Cambridge: Cambridge University Press.

Hughes PD (2008) Response of a Montenegro glacier to extreme summer heatwave in 2003 and 2007. Geografiska Annaler 90A(4), 259-267.

Hughes PD (2009a) Loch Lomond Stadial (Younger Dryas) glaciers and climate in Wales. Geological Journal 44, 375-391.

Hughes PD (2009b) Twenty-first century glaciers in the Prokletije Mountains, Albania. Arctic, Antarctic and Alpine Research 41, 455-459.

Hughes PD and 6 others (2020) Late Pleistocene glaciers to present-day snowpatches: a review and research recommendations for the Marrakech high atlas. Mediterranean Geoscience Reviews 2, 163-184.

Hughes PD and Braithwaite RJ (2008) Application of a degree-day model to reconstruct Pleistocene glacial climates. Quaternary Research 69, 110-116.
Huss M, Dhulst L and Bauder A (2015) New long-term mass-balance series for the Swiss Alps. Journal of Glaciology 61(227), 551-562.

Huss $\mathbf{M}$ and Fischer M (2016) Sensitivity of very small glaciers in the Swiss Alps to future climate change. Frontiers in Earth Science 4(34). doi: 10. 3389/feart.2016.00034.

Institute of Meteorology and Geophysics (2013) Climate Data Vent, Ötztal Alps, 1935-11. University of Innsbruck, PANGAEA. doi: 10.1594/ PANGAEA.806582.

IPCC (2021) Summary for Policymakers. In: Climate Change 2021: The Physical Science Basis. Contribution of Working Group I to the Sixth Assessment Report of the Intergovernmental Panel on Climate Change. (Masson-Delmotte, V, P Zhai, A Pirani, S L Connors, C Péan, S Berger, N Caud, Y Chen, L Goldfarb, M I Gomis, M Huang, K Leitzell, E Lonnoy, J B R Matthews, T K Maycock, T Waterfield, O Yelekçi, R Yu, and B Zhou (eds.). Available at https://www.ipcc.ch/report/ar6/wg1/downloads/report/IPCC_AR6_WGI_SPM_final.pdf.

Jowett AE, Hanna E, Ng F, Huybrechts P and Janssens I (2015) A new spatially and temporally variable sigma parameter in degree-day melt modelling of the Greenland ice sheet 1870-2013. The Cryosphere Discussions 9, 5327-5371. doi: 105194/tcd-9-5327-2015

Juen I and Kaser G (2016) Climate Data Vent, Ötztal Alps, 2012-16. Institute of Atmospheric and Cryospheric Sciences, University of Innsbruck, PANGAEA. doi: 101594/PANGAEA876595.

Juen M, Mayer C, Lambrecht A, Han H and Liu L (2014) Impact of varying debris over thickness on ablation: a case study for Koxkar Glacier in the Tien Shan. The Cryosphere 8, 377-386. doi: 10.5194/tc-8-377-2014

Knight PG (2019) Glacier: Nature and Culture. London: Reaktion Books.

Kuhn M (1979) On the computation of heat-transfer coefficients from energybalance gradients on a glacier. Journal of Glaciology 22(87), 263-272.

Kuhn M (1995) The mass balance of very small glaciers. Zeitschrift für Gletscherkunde und Glazialgeologie 31(1), 171-179.

Kuhn M (2000) Verification of a hydrometeorological model of glacierized basins. Annals of Glaciology 31, 15-18.

Kuhn M and Olefs M (2020) Elevation-dependent climate change in the European Alps. Oxford Research Encyclopaedia of Climate Science, pp. 1-25. doi: 10.1093/acrefore/9780190228620.013.762.

Landsberg HE (1958) Preparing climatic data for the user. Technical Note No. 22, Geneva: World Meteorological Organization.

Liestøl O (1967) Storbreen Glacier in Jotunheimen, Norway. Norsk Polarinstitutt Skrifter, 141.

Linacre E and Geerts B (1997) Climates and Weather Explained. London and New York: Routledge.

Marzeion B, Kasser G, Maussion F and Champollion N (2018) Limited influence of climate change mitigation on short-term glacier mass loss. Nature Climate Change 8, 305-308. doi: 10.1038.s41558-018-0093-1

Menne MJ and 11 others (2012a) Global Historical Climatology Network Daily (GHCN-Daily), Version 3, NOAA National Climatic Data Center doi: 107289/V5D21VHZ (Various dates in 2020).

Menne MJ and 5 others (2012b) An overview of the global historical climatology network-daily database. The Journal of Atmospheric and Oceanic Technology 29, 897-910. doi: 10.1175/JTECH-D-11-001031

National Research Council (1985) Glaciers, Ice Sheets, and Sea Level: Effect of a $\mathrm{CO}_{2}$-Induced Climatic Change. Washington, DC: The National Academies Press. doi: 10.17226/19278.

New M, Hulme M and Jones P (1999) Representing twentieth century spacetime variability. I. Development of a 1961-1990 mean monthly terrestrial climatology. Journal of Climate 12, 829-856.

Oerlemans J (1993a) A model of the surface balance of ice masses: part I alpine glaciers. Zeitschrift für Gletscherkunde und Glazialgeologie 27/28, 53-83.

Oerlemans J (1993b) Modelling of glacier mass balance. In Peltier WR (ed.), Ice in the Climate System. NATO ASI Series 112, Berlin Heidelberg: Springer.

Oerlemans J and Fortuin JPF (1992) Sensitivity of glaciers and small ice caps to greenhouse warming. Science 258, 115-117.

Oerlemans J, Giesen RH and van den Broeke MR (2009) Retreating alpine glaciers: increased melt rates due to accumulation of dust (Vadret da Morteratsch, Switzerland). Journal of Glaciology 55(192), 729-736.

Oerlemans J and Hoogendoorn NC (1989) Mass-balance gradients and climatic-change. Journal of Glaciology 35(121), 394-405.

Oerlemans J, van de Wal RS and Conrads LA (1993) A model for the surface balance of ice masses: part II application to the Greenland ice sheet. Zeitschrift für Gletscherkunde und Glazialgeologie 27/28, 85-96. 
Ohmura A (2012) Enhanced temperature variability in high-altitude change Theoretical and Applied Climatology 110, 499-508. doi: 10.1007/ s0704-012-0687-x.

Pfeffer WT and 10 others (2014) The Randolph Glacier inventory: a globally complete inventory of glaciers. Journal of Glaciology 60(221), 537-587.

Reeh N (1991) Parameterization of melt rate and surface temperature on the Greenland ice sheet. Polarforschung 59(3), 113-128.

Rèveillet M, Vincent C, Six D and Rabatel A (2017) Which empirical model is best suited to simulate glacier mass balances? Journal of Glaciology 63(237), 39-54.

Riseby J and 6 others (2018) A fluctuation in surface temperature in historical context: reassessment and retrospective on the evidence. Environmental Research Letter 13, 123008.

Rogozhina I and Rau D (2014) Vital role of daily temperature variability in surface mass balance parameterization of the Greenland ice sheet. The Cryosphere 8, 575-585.

Sakai A and Fujita K (2017) Contrasting glacier responses to recent climate change in high-mountain Asia. Nature Scientific Reports 7, 13717. doi: 10.1038/s41598-017-14256-5

Seguinot J (2013) Spatial and seasonal effects of temperature variability in a positive degree-day glacier surface mass-balance model. Journal of Glaciology 59(218), 1202-1204.

Thomson L, Brun F, Braun M and Zemp M (2021) Editorial: observational assessments of glacier mass changes at regional and global level. Frontiers in Earth Science doi: 10.3389/feart.2020.641710.

Tsai V and Ruan X (2018) A simple physics-based improvement in the positive degree-day model. Journal of Glaciology 64(246), 661668. doi: 10. 1017jog.2018.55

van den Broeke M, Bus C, Ettema J and Smeets P (2010) Temperature thresholds for degree-day modelling of Greenland ice sheet melt rates. Geophysical Research Letters 37(L18501), 1-5. doi: 1029/2010GL044123

Vincent $\mathbf{C}$ and 9 others (2017) Common climatic signal from glaciers in the European Alps over the past 50 years. Geophysical Research Letters 44, 1376-1383. doi: 10.1002/2016GL072094
Vincent $\mathbf{C}$ and 15 others (2021) Geodetic point surface mass balances: a new approach to determining point surface mass balances on glaciers from remote sensing measurements. The Cryosphere 15, 1259-1276.

von Hahn J (1903) Handbook of Climatology (Translated from German, 2nd ed, 1897). New York: The MacMillan Company.

von Sonklar K (1858) Über den Zusammenhang der Gletscherschwankungen mit den meteorologischen Verhältnissen. Sitzungsbericht der Wiener Akademie 32(1858), 169-206.

von Sonklar K (1866) Die Gebirgsgruppe der Hohen Tauern mit besonderen Rücksicht auf Geographie, Gletscherkunde, Geologie and Meteorologie nach eigene Untersuchungen dargestellt. Vienna, Beck'sche Universitätsbuchhandlung, 408 pp.

Wake LM and Marshall SJ (2015) Assessment of current methods of positive degree-day calculation using in situ observations from glaciated regions. Journal of Glaciology 61(226), 329-344.

Weart S (2008) The Discovery of Global Warming. Cambridge, Massachusetts: Harvard University Press.

WGMS (2020) Fluctuations of Glaciers Database, World Glacier Monitoring Service, Zurich, Switzerland. Online access. doi: 10.5904/ wgms-fog-2020-08.

Winter-Billington A, Moore RD and Dadic R (2020). Evaluating the transferability of empirical models of debris-covered glacier melt. Journal of Glaciology 66(260), 978-995. doi: 10.1017/jog.2020.57.

Xie Z, Ding L, Liu C and Liu S (1996) Mass balance of the steady-state equilibrium line altitude and its application. Journal of Glaciology and Geocryology 18, 1-9 (in Chinese).

Zemp $\mathbf{M}$ and 32 others (2015) Historically unprecedented global glacier decline in the early 21 st century. Journal of Glaciology 61(228), 745-762.

Zemp M and 13 others (2019) Global glacier mass changes and their contributions to sea-level rise from 1961 to 2016. Nature 568. doi: 10.1038/ s41586-019-1071-0.

Zingg T (1952) Beziehung zwischen Temperature und Schmelzwasser und ihre Bedeutung für Niederschlags- und Abflussfragen. Publication of Association of Hydrological Sciences 32(1), 266-269. 